\title{
THE MUGHAL AUDIENCE HALL: A SOLOMONIC REVIVAL OF PERSEPOLIS IN THE FORM OF A MOSQUE ${ }^{1}$
}

\author{
Ebba Koch
}

\section{Shah Jahan's Court}

After Shah Jahan (rul. 1628-58), the fifth emperor of the Mughal dynasty, was enthroned on 8th Jumada al-Thani of the Hijri year 1037, corresponding to 14 February $1628 \mathrm{CE}$, he issued an order that halls for his public audiences should be constructed in all the great fortress palaces of the capitals of the Mughal empire. The audience hall was a new building type in the Mughal palace, of central importance for the proceedings of the Mughal court and for the interaction of the emperor with his subjects.

Under the rule of Shah Jahan, the Mughal empire entered its classical phase of greatest prosperity and stability. ${ }^{2}$ The conquests of Babur (1526), enlarged and consolidated under Akbar (rul. 1556-1605) and Jahangir (rul. 1605-1627), had established the Empire of the Great Moghul (or Mughal) as one of the three leading powers of the Islamic world, the other two being the Ottoman Empire and Safavid Persia. The informal set up of Babur as primus inter pares among his Central Asian followers, had-in particular through the efforts of Akbardeveloped into the court of an absolute ruler who, as head of a centralized state, personally and diligently oversaw the administration of

1 This paper is based on an earlier study of the audience halls of Shah Jahan with detailed references, see Ebba Koch, 'Diwan-i 'Amm and Chihil Sutun: The Audience Halls of Shah Jahan', Muqarnas 11 (1994) pp. 143-165; available in the internet under $<$ http://www.archnet.org/library/documents/one-document.tcl?document_id=3696>. In the present reassessment I have put the halls into the context of Shah Jahan's court, condensed the argument and added new references as well as several new observations, especially in regard to the connection of audience hall and mosque.

${ }^{2}$ For this and the following see Ebba Koch, 'The Hierarchical Principles of ShahJahani Painting', in: Milo C. Beach and Ebba Koch, King of the World: The Padshahnama: An Imperial Mughal Manuscript from the Royal Library, Windsor Castle, Wheeler Thackston, trans. (London; Washington, D.C. 1997) pp. 130-143, with further references; Ebba Koch, Mughal Art and Imperial Ideology: Collected Essays (New Delhi 2001) pp. 130-162. 
his vast empire, supported by his amirs and mansabdars, the militarily structured ruling elite. Distinction in the hierarchy of the bureaucratic apparatus had to be acquired through personal achievement, as acknowledged by the emperor; even the succession to the throne was not regulated by primogeniture. This fused the ruling classwhose members belonged to diverse ethnic and religious communities reflecting the heterogeneous components of the empire-into a coherent administrative body which, by the time of Shah Jahan, depended entirely on the emperor. This was particularly true of the Muslim nobles. The indigenous Rajput chieftains, when incorporated into Mughal service, were able to retain some of their independence, such as the hold over their ancestral dominions. Since the imperial authority represented the main guaranty for the functioning of the hybrid political system, the emperor's appeal to a purely personal loyalty depended largely on his personal charisma which was supported and magnified by the myth created for his kingship. Here the Mughals drew with their own disarming lack of inhibition on all the notions of kingship they could lay their hands on and which they deemed suitable to be put into the service of their cause. These included Muslim caliphal, Qur'anic prophetic and Sufi; Achaemenian and Sasanian Persian, and Perso-Islamic; Turko-Mongolian; Hindu and Islamic Indian; Christian-Messianic and recent European concepts of universal monarchy. Within this eclectic array each ruler set his own accent.

\section{Court Ceremonial and its Buildings}

The hierarchic relationship between Shah Jahan and his subjects was confirmed and acted out symbolically in a rigid court ceremonial, focusing on the emperor, which was repeated daily. Hand in hand with the regulation of every detail of court life went an ever-increasing formalization of the court arts which were represented as a necessary instrument of rule. The ruler who exerted himself in the sphere of artistic representation was sure of the loyalty, obedience and recognition of his subjects, as well as of the esteem of his rival rulers. This is put into words by the historian Muhammad Salih Kanbo in one of the rare self-reflective passages which tell us how the purpose of pomp and show was perceived at the Mughal court. It is found in his history of Shah Jahan, the Shah-Jahannama or 'Amal-i Salih (completed 1659-60): 
Whenever the highest Wisdom of the Majesty exalted above all [God]may His proof be exalted everywhere-out of concern for His servants and His countries finds it apt to choose a dynastic family of sultans of the world, He bestows special distinction on the lords of that God-given empire among all other masters of empires with perfect grandeur and majesty and He gives necessarily whatever is essentially connected with [maintenance] of the rule. Such matters may belong [to the category] of beautiful and external things the existence of which is not so necessary [in the context] of overall rule, but they must be [present] to give full distinction and spectacular display-the more so since it becomes a matter of increase of pomp and power, magnificence and elegance...It is evident that the increase of such things creates esteem for the rulers in the eyes [of the people] and augments respect [for the ruler] and [their own] dignity in [their] hearts. In this form the execution of divine injunctions and prohibitions and the enforcement of divine decrees and laws which is the ultimate aim of rulership and kingship are carried out in a better way. ${ }^{3}$

Pomp and show, ceremonial, architecture and the arts were emphasized as indispensable instruments of rulership. This conformed to prevailing ideas in the Islamic world where architecture and the arts had long been considered as the immediate expression of the ruler, true to the Arabic saying 'Athar-una tadu-ll-alina'- 'Our monuments will speak of us.' The great Arab historian Ibn Khaldun (1332-82), in his famous work al-Muqaddima, the 'Introduction' to history, had drawn attention to the decisive role Muslim rulers played in the development of architecture and the crafts which served as their status symbol and to the fact that their patronage was echoed by the nobility and the urban classes of the cities, the centres of power, religion, learning and culture. ${ }^{4}$ In Europe such ideas did not manifest themselves widely until the age of absolutism from the 16th century onwards, when the leading role of the church as patron of the arts was challenged by worldly rulers.

${ }^{3}$ Muhammad Salih Kanbo, 'Amal-i Salih or Shah-Jahannama, Wahid Qurayshi, rev. and ed., based on the Calcutta edn of 1912-46 by Ghulam Yazdani, 2nd edn (Lahore 1967-72) vol. 3, p. 25; as translated in Ebba Koch, 'The Baluster Column: A European Motif in Mughal Architecture and Its Meaning', Journal of the Warburg and Courtauld Institutes 45 (1982) p. 259; Ebba Koch, Mughal Art and Imperial Ideology: Collected Essays (New Delhi 2001) pp. 38-60.

${ }^{4}$ Ibn Khaldun, The Muqaddimah, An Introduction to History, F. Rosenthal, trans., and abridged by N.J. Dawood (London 1967) pp. 216, 263-266, 314-317, 319-321, 327-332, et passim; cf. Doris Abouseif, Beauty in Arabic Culture (Princeton 1999) pp. 159-185. 
Shah Jahan's approach stands out in the consistent systematization of highly aestheticized form as an expression of his specific state ideology, of centralised authority and hierarchy bringing about balance and harmony. A counterpart, if not a follower, in the West would be Louis XIV of France (rul. 1643-1715) whose use of ceremony, art and architecture as an instrument of absolute monarchy was in turn emulated by other European courts. ${ }^{5}$

Shah Jahan and his advisers structured court proceedings with a rigid ceremonial which, if we are to believe his historians, he himself followed to the minute in his daily routine. From morning to evening Shah Jahan moved from one place of interaction with his court and subjects to another. The audiences were progressively limited in access, from the most public form in the viewing window or Jharoka-i Darshan on the outer wall of the palace to the great darbar in the Public and Private Audience Hall, the Daulat Khana-i Khass-u-'Amm (or Diwan-i 'Amm in short form), to the Hall of Private Audiences, where the main government business was conducted, the Daulat Khana-i Khass or Diwan-i Khass, to the Royal Tower, the Shah Burj, the chamber of secret councils, and from there to the most remote form of audience in the Harem or zanana, the female palace where the affairs of the women were regulated. The appearance in the Jharoka-i Darshan took place only in the morning at sunrise, when the emperor appeared to his subjects as 'the earthly sun opposite the sun in the sky', as a true sun ruler spreading bounty; the remaining cycle was repeated in the afternoon. ${ }^{6}$

Not only were the assemblies standardized but also their architectural frame. For each 'station' of the emperor's movement through the palace there was a specifically designed building, and its shape followed, within a margin of variation, the similar formal criteria (or showed a similar configuration of components) in all imperial palaces. The form of a palatial building can thus tell us about its function. The most standardized type in the programme of palace buildings was the

\footnotetext{
${ }^{5}$ For Louis XIV's interest in 'Oriental rulers', see Gülru Necipoğlu, 'Framing the Gaze in Ottoman, Safavid, and Mughal Palaces', Ars Orientalis 23, special issue: Premodern Islamic Palaces (1993) p. 317.

6 'Abd al-Hamid Lahawri, Padshahnama, M. Kabir-ud-Din Ahmad and M. 'Abd alRahim, eds. (Calcutta 1865-72) vol. 1, pt. 1, pp. 144-154; translated Nur Bakhsh, 'The Agra Fort and Its Buildings', Archaeological Survey of India Annual Report (1903-4) pp. 188-193.
} 
hall for public audience, a new invention of Shah Jahan, and the subject of our discussion.

\section{The Audience Halls}

New halls for public audience were constructed after Shah Jahan's accession in the great fortress palaces of the Mughal empire, at Agra, Lahore, and, according to some sources, also at Burhanpur in central India. These halls were first built in wood to replace a smaller tent hall that had been used for the purpose up to then. As we can see from the images illustrating the history of Shah Jahan's reign (Fig. 1), the wooden halls were hypostyle constructions with green pillars topped with red elements ${ }^{7}$ and the court poet Abu Talib Kalim compared the first hall at Agra to a garden full of cypresses

This new building which is under the same shadow as the Divine Throne ('arsh) [meaning that is on the same level in the highest stage of heaven]

Loftiness is a mere word with regard to the position of its plinth.

It is a garden of which every green pillar is a cypress

And high and low find rest under its shadow. ${ }^{8}$

The historians also give us the dimensions of the wooden hall (iwan-i chubin) of Agra which was enormous, namely 70 gaz padshahi long and $22 \mathrm{gaz}$ wide, corresponding to $56.89 \mathrm{~m} \times 17.88 \mathrm{~m}$ because the gaz employed in Shah Jahan's architecture had (ideally) a length of $81.28 \mathrm{~cm}$ or 32 inches.

By January 1637, the wooden halls of Agra and Lahore had in turn been replaced by even larger permanent versions, constructed "of red sandstone made white with marble plaster" (Fig. 2). Between 1639 and 1648 a corresponding stone hall was built in the emperor's new palace at Shahjahanabad (Delhi) (Fig. 3).

All of these halls including their wooden precursors are described by Shah Jahan's historians and poets as Iwan-i Dawlat Khana-i Khassu-'Amm, and Iwan-i Chihil Sutun. Iwan means in Mughal Persian a pillared construction of any dimension and plan; dawlat khana can be rendered in English as 'house of royal power and authority' and

\footnotetext{
7 Beach and Koch, The Padshahnama, cat. nos. 14, 32, 43, 44.

${ }^{8}$ Kalim's verses are cited by Lahawri, Padshahnama, vol. 1, pt. 1, pp. 221-223 where he gives a description of the Agra hall.
} 


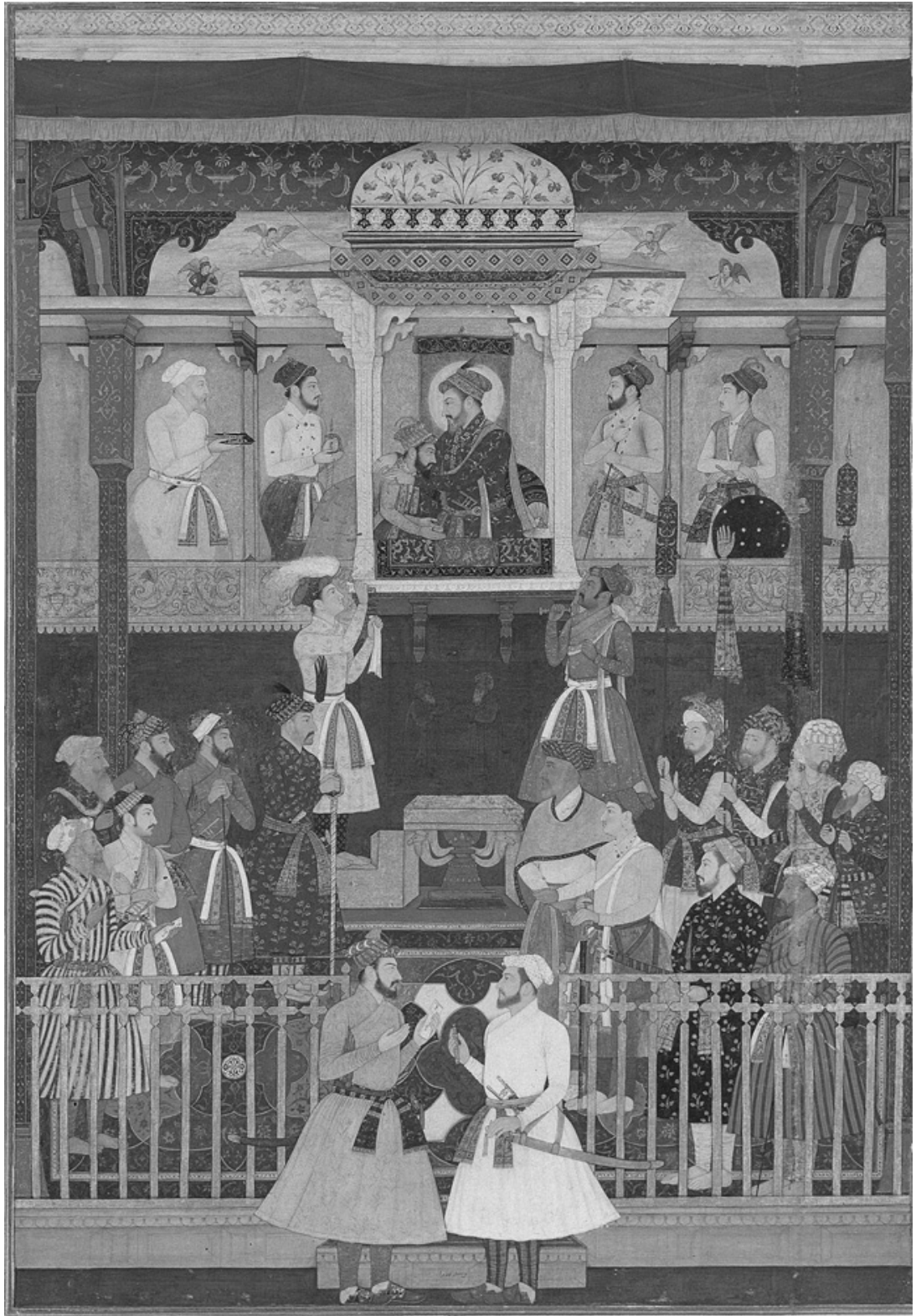

Figure 1. Shah Jahan receives his son Awrangzeb in the Hall of Public Audience or Diwan-i 'Amm of Lahore, painted by Murar, ca. 1645, Royal Library, Windsor, Copyright 2006, Her Majesty Queen Elizabeth II. 


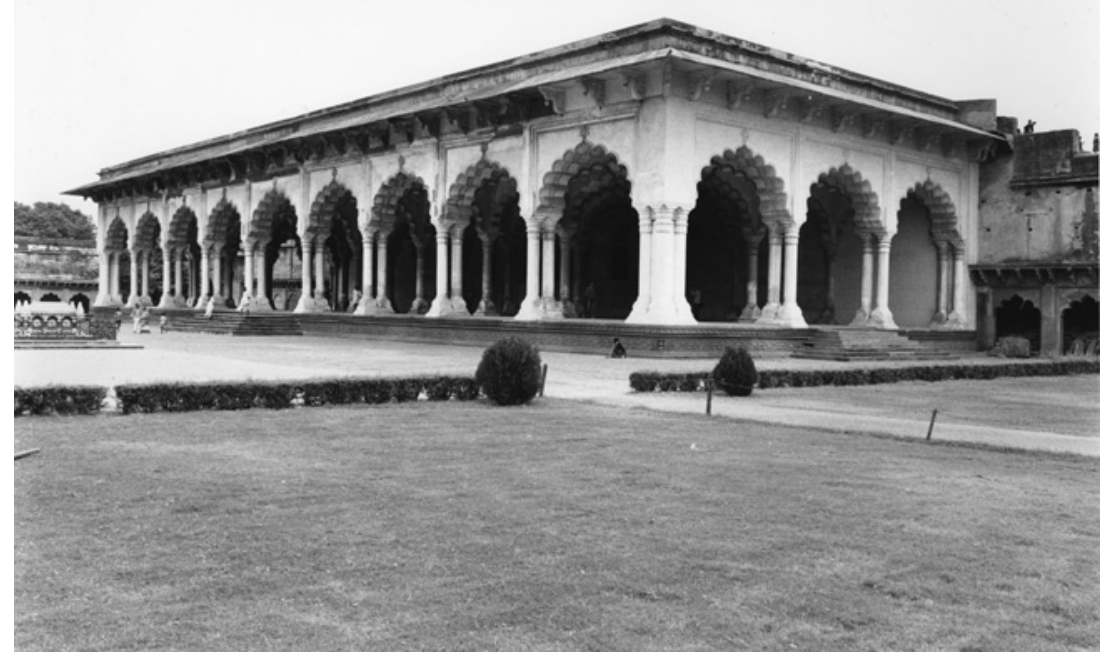

Figure 2. Diwan-i 'Amm, Agra, completed 1637 (Photo Ebba Koch).

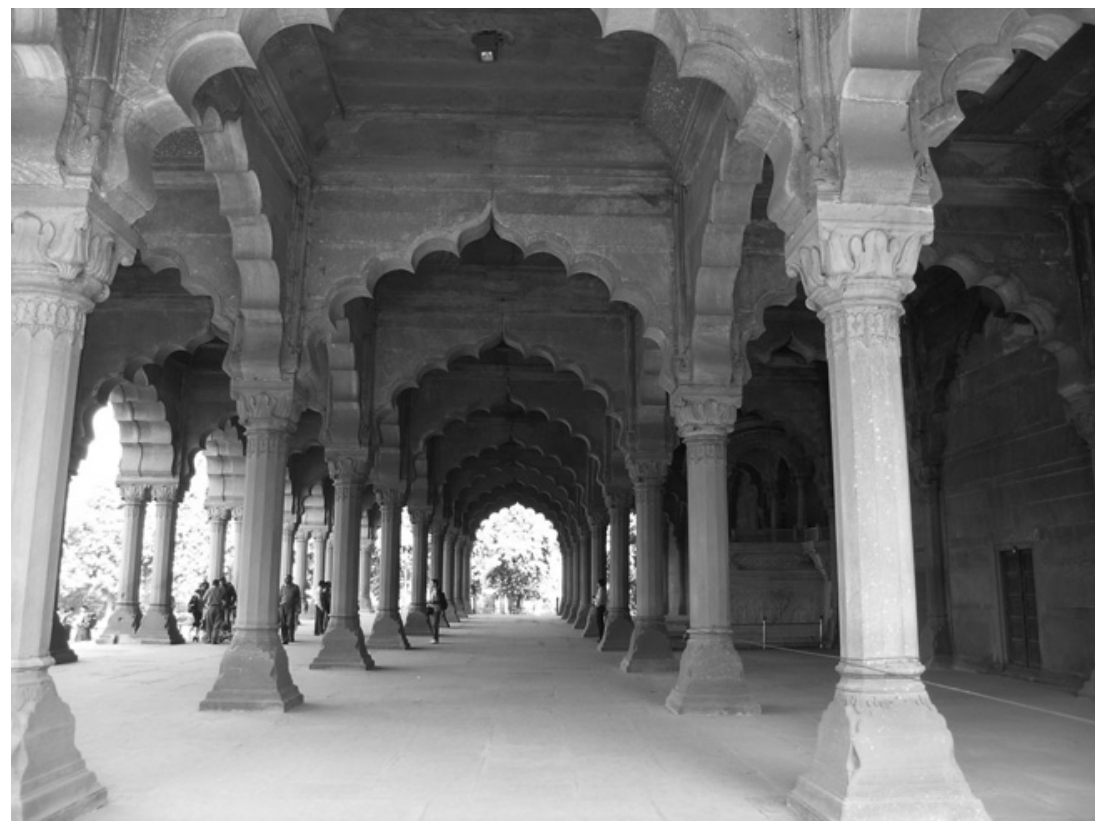

Figure 3. Diwan-i 'Amm, Delhi, completed 1648 (Photo Ebba Koch). 
is used for an imperial palace or palace building; khass, meaning the special, the close ones, referred to the group which represented the highest ranks of the empire; and 'amm were all the others. Iwan -i Dawlat Khana-i Khass-u- 'Amm can thus be translated as state hall for high and low or Hall of Public Audience. Iwan-i Chihil Sutun means Hall with Forty (Chihil) Pillars (Sutun). The Dawlat Khana-i Khassu- 'Amm, (Diwan-i 'Amm in short form), or Iwan-i Chihil Sutun represents a new type in the palatial building program of the Mughals because, as the sources tell us, under the predecessors of Shah Jahan most of those who took part in the audience had to stand unprotected from sun and rain in front of the emperor's viewing window or Jharoka in the open courtyard, the Sahn-i Khass-u-'Amm, where the audience was held (Fig. 4a). The emperor, we are told, ordered the construction of the halls out of concern for his nobles, to protect them from the vicissitudes of the weather. And we also learn that the halls made it easier to maintain the proper hierarchy and etiquette of an audience which, as we have seen, were aspects of special concern to Shah Jahan. The public audience or bar-i 'amm was also a state council and attendance was obligatory for every Mughal officeholder present at the residence, whether amir or mansabdar. The nobles and their retinues had to stand positioned according to their rank in front of the Jharoka-i Khass-u 'Amm (Fig. 1), the place of appearance of the emperor along the back wall of the hall, from where he dealt with the administration of the imperial household and the empire (which was treated like its extension) and other affairs of state.

The new audience halls were put up in front of the wall with the Jharoka and were only accessible to holders of a certain rank, namely those courtiers who had a mansab above two hundred. The halls were open on three sides and to ensure restricted access, they were enclosed on the outside by a silver railing, the three doors of which were closely guarded. An additional space, fenced off by a red railing which surrounded the halls at some distance, was reserved for those with a mansab below two hundred. The remaining area of the Sahn-i Khass-u-'Amm was used by retainers and others without any particular rank (Figs. $4 a$ and $b$ ).

\section{Function of the Audience Halls}

In addition to being a place of daily proceedings in the government of the Mughal empire the Diwan-i 'Amm provided a stage for the great court festivals, in particular Nawruz, the Persian New Year which was 


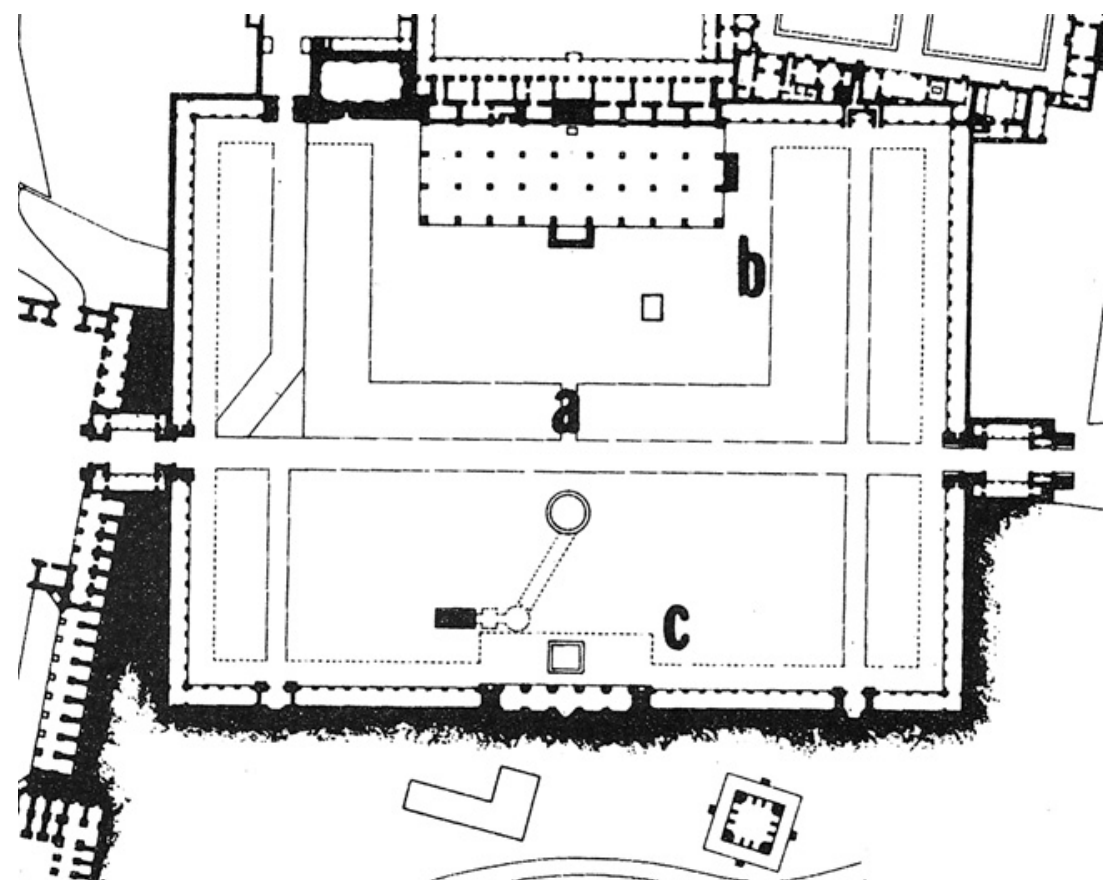

Figure 4. Site plan of Agra Fort, detail, (a) courtyard of khass-u-'amm; (b) Diwan-i 'Amm hall; (c) mosque (Drawing: R.A. Barraud and E. Koch).

celebrated with great pomp and show at the Mughal court, and julus, the anniversary of the emperor's accession to the throne. It was also the setting for such state ceremonies as the weighing of the emperor on his solar and lunar birthdays (jashn-i wazn-i shamsi, jashn-i wazn- $i$ qamari). When a royal prince's wedding was held, the Diwan-i 'Amm was at times called khalwat ("seclusion" or "retirement"), because on those occasions men had to evacuate the courtyard to allow the imperial women to use the Diwan-i 'Amm as an exhibition hall where they arranged the dowry and the wedding presents for display to the court during the emperor's public audience. The audience hall played also a part in the celebration of religious festivals such as the 'Id. The emperor also hosted scholars and pious persons with a banquet there on the Milad (the Prophet's birthday). During the whole month of Ramazan fast-breaking meals (iftar) would be given to deserving poor persons at imperial expense in the audience hall. The emperor also used it to receive foreign dignitaries and delegations. All in all, the Diwan-i 'Amm was the center of court events and Mughal rule where the power and pomp of the Grand Moghul was enacted. 


\section{Sources of the Audience Halls as Chihil Sutuns (Forty-Pillared Halls)}

The halls are described by Shah Jahan's historians, 'Abd al-Hamid Lahawri and Muhammad Salih Kanbo, ${ }^{9}$ and there are also reports of contemporary European eye witnesses. These literary sources tell us what the various functions of the halls were and something about their form, but not what would also interest the modern architectural historian, namely, why such a monumental hypostyle audience hall was introduced in the palace architecture of the Mughals. Aside from panegyric comparisons and poems written when a hall of Shah Jahan was completed, the sources have nothing to say about their architectural programme. This should not surprise us because direct statements about the meaning of architecture, indeed of works of arts altogether, are not a special genre of Mughal writing. Contemporary interpretations are often embedded in a more or less enciphered form in the courtly panegyric. The greatest problem here is to recognize which themes and concepts were merely literary conventions and which had an actual bearing on a work of art.

Shah Jahan's court historians, by designing the halls as Chihil Sutun, provide us with a clue about their concept. In Iran the term was used in the sense of halls with many, though not necessarily forty, columns. The Safavids who ruled over Iran during the period of the Mughal empire used it in this way.

The Mughals considered their immediate neighbours, the Safavids, their greatest rivals. They also wanted to measure themselves against the Persians on the level of the arts, so Iran became an important factor for the concept of Mughal rulership. It is well known that their great ancestor Timur had tried to establish himself as a TurcoMongolian warlord and conqueror in the Persian-Islamic tradition of rulership. His successors, the Timurids, oriented themselves even more strongly towards Persianate culture. Given this orientation of the Mughals towards Iran, one is tempted to relate the sudden appearance of Mughal audience halls designated with the Persian term chihil sutun to the hypostyle porticoes or talars of the reception pavilions of the Safavids, because they are formally and functionally related. One feels in particular inclined to make this connection because the first version

\footnotetext{
${ }^{9}$ Lahawri, Padshahnama, vol. 1, pt. 1 pp. 144-154; translated Bakhsh, 'The Agra Fort and Its Buildings', pp. 188-193; Kanbo, Shah Jahannama, vol. 1, pp. 201-210.
} 


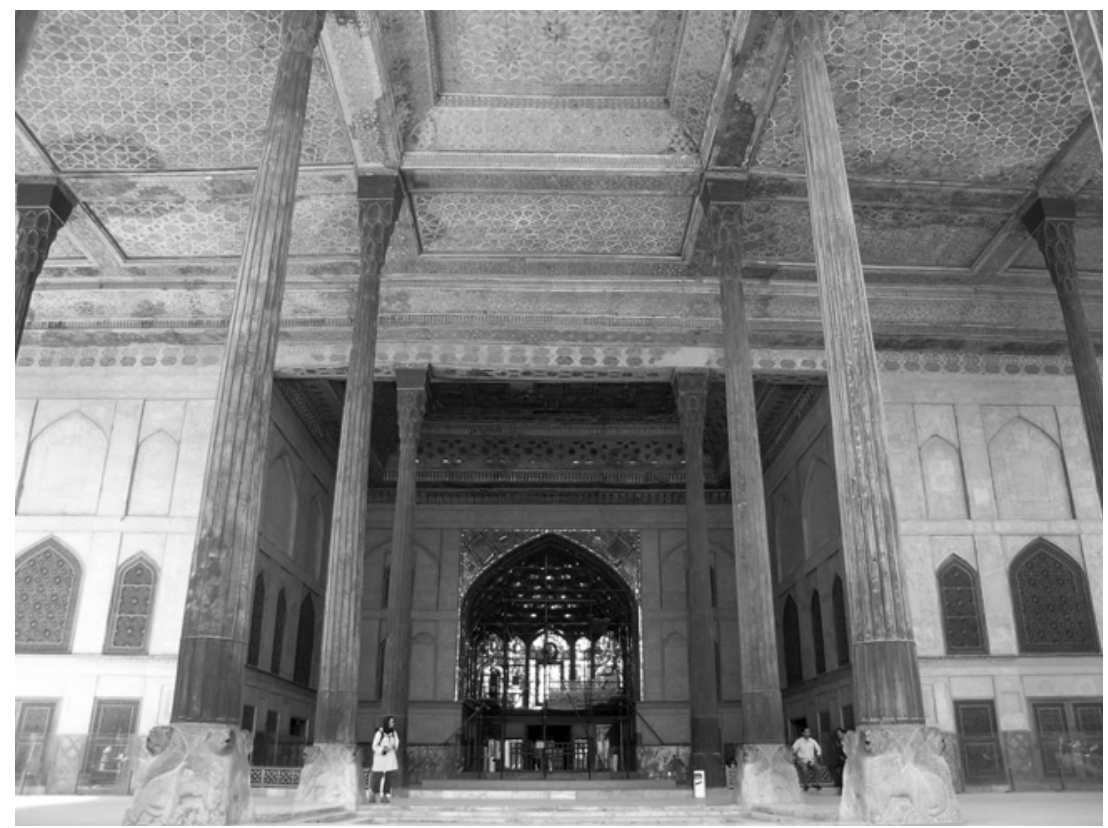

Figure 5. Chihil Sutun, Isfahan, 1647 (Photo Ebba Koch).

of Shah Jahan's Chihil Sutuns was-like the Safavid talars-a hypostyle wooden construction open on three sides set before a masonry wall with a seat for the shah in the centre.

The problem, however, is that neither the date nor the origin of the Safavid talars has as yet been established with certainty. The immediate namesake and functional equivalent of Shah Jahan's Chihil Sutuns, the reception pavilion in the palace of Isfahan dates, in its present form, from 1647 (Fig. 5). The shape of the earlier Safavid Chihil Sutun at Qazwin is uncertain. ${ }^{10}$ Buildings called Chihil Sutuns occur also in the Timurid context, the best known of which is the one Ulugh Beg built in the first half of the fifteenth century at Samarqand. Although it has not survived, we know from Babur that it had stone columns arranged in two stories.

${ }^{10}$ Sussan Babaie, Isfahan and Its Palaces: Statecraft, Shi'ism and the Architecture of Conviviality in Early Modern Iran (Edinburgh 2008) pp. 53-55, 157-182. 


\section{References to Persepolis as Chihil Sutun and site of the Iranian Kings} and Solomon

However, among the sites known as Chihil Sutun in the earlier seventeenth century there was one of particular historical significance which predates all the Chihil Sutuns discussed so far. In connection with audience halls it must have been pivotal for the Iran-inspired concept of rulership of the Mughals. This is Persepolis, the great ritual and representative centre of the Achaemenid empire, the place where the ceremonies of the world-ruling Persian kings were held in multicolumned audience halls (Fig. 6). Alexander the Great had destroyed Persepolis but it remained over the centuries a symbolically highly charged place for any ruler who sought to associate himself with the Persian concept of sacred kingship. This is even true of the Habsburg rulers of the Holy Roman Empire. Their great architect Josef Bernhard Fischer von Erlach is said to have planned the new royal palace at Schönbrunn in Vienna on a hill in the same way as it is reported of the royal castle at Persepolis or Tschehelminar, so that His Majesty [Charles VI, 1685-1740]-like Cyrus overlooking his empire-can see as far as the borders of Hungary.'.

In Iran, the references to Persepolis begin with the Sasanians who, incidentally, came from the region of Istakhr where Persepolis is situated. The tradition was continued by the Muslim rulers beginning with the Buyids (tenth century) who sought to establish their royalty in face of the 'Abbasid caliphs at Baghdad, the spiritual rulers of Islam. The unbroken associations of Persepolis with the Iranian-Muslim tradition of kingship are evident from Arabic and Persian inscriptions of Muslim princes who visited Persepolis throughout the centuries. The engraved inscriptions of these royal visitors are still to be found in the palace of Darius, the Tachara. They have similar contents and, at times, even copy from each other, clearly to emphasize the aspect of continuity related to the place. Their themes reflect on the transitory nature of human achievement, in particular of worldly power and kingship, thoughts which were considered as befitting for princes contemplating ancient sites. An example comes from Ibrahim Sultan, the son of Shah Rukh, a relative of the Mughals and a highly ambitious

${ }^{11}$ Georg Kunoth, Die historische Architektur Fischers von Erlach (Düsseldorf 1956) pp. 120-124, pl. 102. 
Timurid governor of Fars. In the year 826/1423 he left the following verses on the palace of Darius:

Do you know any one of the old kings of Iran

of the time of Faridun, Zahhak or Jam[shid]

Whose throne and empire did not perish and who was not

ruined by the hand of destiny?

Did not the throne of Solomon-peace be upon him-

from morning to evening fly upon the wind?

Did you not see that finally it was gone with the wind?

Happy the one who departed, leaving behind knowledge and justice!

Beware! that you bring up the tree of generosity-no doubt

you will then taste the fruits of fortune.

Written by Ibrahim Sultan bin Shah Rukh in the year

eight hundred twenty-six. ${ }^{12}$

The verses tell us that, in Islamic Iran, Persepolis was not associated with its historical founders, the Achaemenids, but with the mythical rulers of Iran as they were popularized by Firdawsi's great epic of kings, the Shah nama (written around $1000 \mathrm{CE}$ ), in particular with Jamshid. In Muslim Iran Persepolis was (and still is) not only known as Chihil Sutun or Chihil Minar but also as Takht-i Jamshid (Throne of Jamshid). The Arab tradition too claimed Persepolis under the name of nearby Istakhr, by regarding it as a place of Solomon, who, in the Koran and Muslim legends, appears as prophet king and ideal ruler of Islam. The Arab geographers of the Middle Ages from about the 10th century onwards like Istakhri, Muqaddasi or Mas'udi described Persepolis as mal'ab-i-Sulayman a playground of Solomon and in particular as masjid-i Sulayman, as mosque of Solomon. ${ }^{13}$ In popular Persian tradition Jamshid and Solomon were amalgamated into one and the same person. ${ }^{14}$ Davani, for instance, who writes in 1476 about Persepolis, says that it is known as Chihil Sutun and that it was founded by

${ }^{12}$ My translation from the French translation of A.S. Melikian-Chirvani, 'Le royaume de Salomon: les inscriptions persanes de sites achéménides', Le Monde iranien et l'Islam 1 (1971) pp. 24-25.

${ }_{13}$ Paul Schwarz, Iran im Mittelalter nach den arabischen Geographen, vol. 1 (Leipzig 1896) pp. 13-16.

${ }_{14}$ Georg Salzberger, Die Salomo-Sage in der semitischen Literatur. Ein Beitrag zur vergleichenden Sagenkunde (Berlin 1907) pp. 2-5, 8, 23; and Georg Salzberger, Salomos Tempelbau und Thron in der semitischen Sagenliteratur, Schriften der Lehranstalt für die Wissenschaft des Judentums 2, 1 (Berlin 1912) p. 57. Colin P. Mitchell (The Practice of Politics in Safavid Iran: Power, Religion and Rhetoric [London 2009], pp. 120-44) has recently also referred to this issue in his discussion of Solomon as an exemplar of rulership of the Safavids. 
Jamshid whom tradition identifies with Solomon. ${ }^{15}$ From the German observer Engelbert Kämpfer we learn that Persepolis as Chihil Sutun or Chihil Minar (Forty Towers) was as strongly connected to Solomon in the late seventeenth century as in the earlier periods. He reports that it was believed to be the seat of Solomon and the model of the Solomonic temple. ${ }^{16}$

\section{The Mughal Audience Halls as a Solomonic Reference to Persepolis}

Both traditions, that of the ancient Persian kings as well as that of Solomon, were fundamental to the concept of rulership of the Mughals. That the Great Mughals liked to appear as second Khusraws (synonym for Sasanian kings), as second Jamshids, and as second Solomons, is transmitted through their courtly panegyric as well as through the arts created for them. Like other Muslim princes, the Mughals were keen to compare themselves with Solomon, but they were unique in their visual realisation of Solomonic schemes in art and architecture. The theme of the Solomonic prophet king became predominant from the time of Jahangir (r. 1605-27) onward and was also used for his son and successor, Shah Jahan. ${ }^{17}$

Both themes, that of the Persian kings and that of Solomon, are featured also in the panegyric written upon the completion of the audience halls of Shah Jahan. Beside the more general allusions of Lahawri who praises the heaven-reaching loftiness of the wooden Agra hall and its stone replacement, and the repeatedly quoted ruba' $i$ (quatrain) of Abu Talib Kalim who, as we have learnt, compares the columnar construction of the wooden Agra hall to a garden full of shade-giving cypresses, it is Muhammad Salih Kanbo who informs us which particular buildings and sites the Mughals associated with the audience halls. Kanbo relates both the wooden hall of Agra (1637) and the stone hall of Delhi (1648), which he describes as bargah (iwan)- $i$ chihil sutun (forty-pillared state hall), diwankada-i 'adl-u-dad (court house of equity and justice) and bargah-i Sulaymani (Solomonic hall)

\footnotetext{
15 A.S. Melikian-Chirvani, 'Le royaume de Salomon, les inscriptions persanes de sites achéménides', Le monde iranien et l'Islam I (1971) pp. 1-41, pp. 2-3, 26 ff.

${ }_{16}$ Engelbert Kämpfer, Amoenitatum exoticarum politico-physico-medicarum (Lemgo 1712) pp. 302, ff. 326.

${ }^{17}$ Koch, Mughal Art and Imperial Ideology, pp. 12-37, 104-129; Ebba Koch, 'The Mughal Emperor as Solomon, Majnun and Orpheus or the Album as a Think Tank for Allegory', Muqarnas 27 (2010) pp. 277-311.
} 
to several famous legendary and historical palaces of the past, in particular to the iwan-i Nushirwan, the sab-i Shaddad and, again, the bargah-i Sulayman. Such passages should not be dismissed as superfluous eulogical exercises, as past translators of historical Mughal texts have often done. Court panegyrics represent an indispensable source for establishing the meaning of a Mughal work of art.

When we look critically at Kanbo's eulogical comparisons mentioned above which, because of their repeated use, appear to have had a special relevance for Shah Jahan's halls, we immediately recognize that the reference to the iwan-i Nushirwan belongs to a definite literary tradition alluding to 'the global sovereignty claimed by the Sasanian King of Kings from his fabled palace at Ctesiphon'. ${ }^{18}$ In Arabic and Persian literature the Ctesiphon palace was known as Iwan-i (Khusraw) Nushirwan, and also called Taq-i Kisra (Arch of Khusraw) and under both names it was used proverbially to refer to any grand royal building. In the context of the audience halls of Shah Jahan the reference appears to have an additional terminological significance because it plays on the flexible meaning of iwan, a word Shah Jahan's authors did not use for a monumental vaulted hall open at the front, but in the Central Asian sense of a pillared construction, similar to the way the Iranians use the term chihil sutun.

Kanbo's claim that Shah Jahan's halls were a copy (nuskhat) of the $s a b$ - $i$ Shaddad (seven [layered construction] of Shaddad) refers to the legendary Iram at Aden built by King Shaddad bin 'Ad as a paradise on earth. The connection to Shah Jahan's halls could be that it was, as the Koranic sura 89:6, says "of Columns."

But what about bargah-i Sulayman? Did Kanbo refer generally to a Solomonic hall or did the reference have a more specific significance? First of all bargah in Mughal Persian has the precise architectural meaning of audience tent or audience hall; accordingly, Shah Jahan's halls are also called bargah-i chihil sutun. Second, by the time of Shah Jahan's accession in 1628, after which the first wooden versions of the audience halls were constructed, Solomonic imagery had already made a strong impact upon the arts of the Mughal court; Jahangir had used it extensively in the decoration of his palaces. Consequently, in Mughal eulogies of a building of that time, any reference to Solomonic imagery must be taken seriously, which means that it may well have

\footnotetext{
${ }_{18}$ John Renard, Islam and the Heroic Image: Themes in Literature and the Visual Arts (Columbia, SC 1993) p. 169.
} 
a bearing on the actual architecture. This applies in particular to the audience halls, because the gathering of Shah Jahan's courtiers in front of the emperor in the Jharoka-i Khass-u 'Amm would evoke among contemporaries strong Solomonic associations. Qazwini, for instance, calls it majlis-i diwan-i Sulayman-i zaman, "the court assembly of the Solomon of the Age" (Fig. 1). True, Kanbo does not tell us what exactly he had in mind when he calls Shah Jahan's audience halls bargah-i Sulaymani or compares them favourably to the bargah-i Sulayman. However, in connection with the designation of the halls as Chihil Sutun, the name under which Persepolis was known, we are on safe grounds in assuming that, in the whole chain of panegyrical comparisons, bargah -i Sulayman [i] was the one notion which advertised the symbolic and architectural program. The Shahjahani halls would therefore have been meant as a deliberate quotation of the most famous and most ancient Chihil Sutun of Iran, the audience halls of Persepolis, believed to have been founded by Solomon-Jamshid. This connection was intensified by the traditional association of Persepolis with Nawruz, and Davani reported that Jamshid-Solomon celebrated Nawruz there. ${ }^{19}$ In a comparable way Shah Jahan's Chihil Sutuns in the courtyard of khass-u-'amm acquired their greatest splendour during the yearly Nawruz celebrations of the Mughal court.

\section{The Mughal Halls as a Recreation of Chihil Sutun (Forty Pillared)-Persepolis}

How then could the Mughals have expressed the reference to Chihil Sutun-Persepolis architecturally over such great distance of time and space? Up to the seventeenth century the main thing that was known about the great audience halls of Persepolis was that they had many columns-namely chihil sutun - of which only a few were left standing (Fig. 6). The way of referring to Persepolis with synonyms of "manycolumned" can be traced as far back as the Sasanians, who designated it as "Sat Sutun" (of a hundred columns). Muslim writers such as Davani tell us that "in the time of the [old] Persian kings" (muluk-i 'Ajam) Persepolis was called "Hazar Sutun" (of a thousand columns). The latter brings to mind the famous Hazar Sutun of the Delhi sul-

\footnotetext{
${ }^{19}$ See V. Minorsky, 'A Civil and Military Review in Fars in 881/1476', Bulletin of the School of Oriental and African Studies, 10 (1940) pp. 141-178, at pp. 150-51.
} 


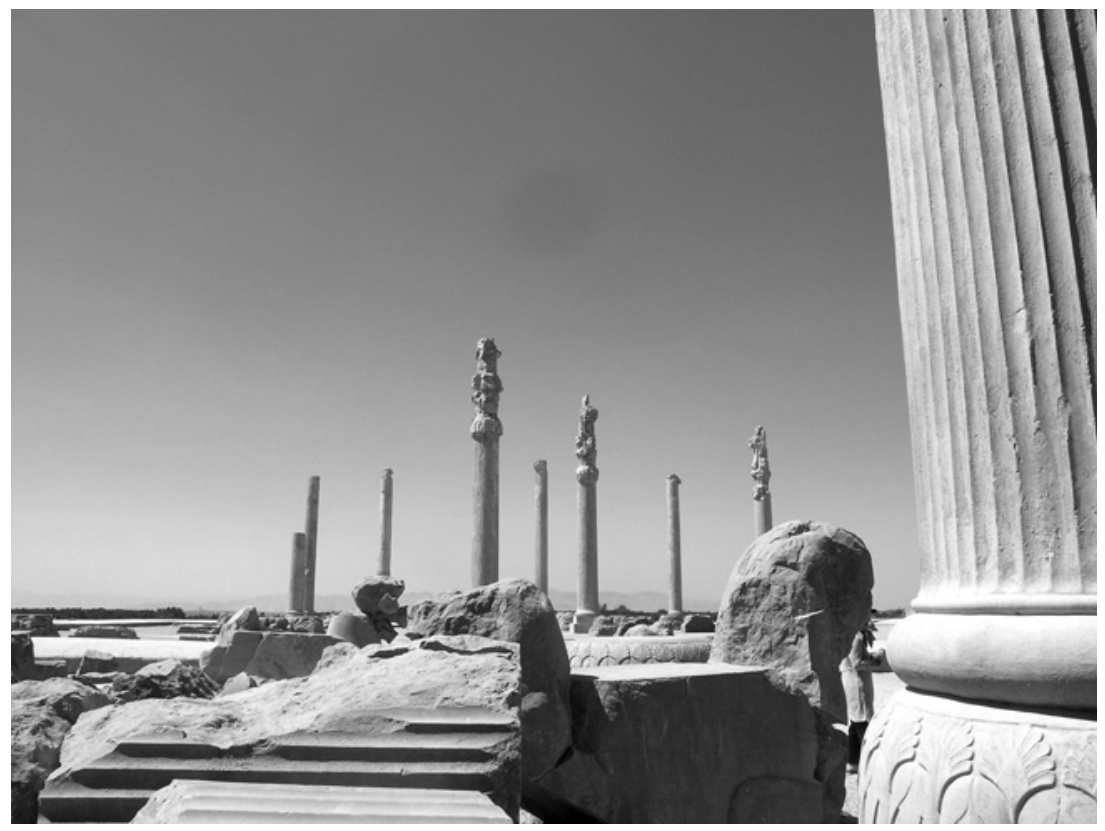

Figure 6. Persepolis, Apadana (c. 500-490 BCE) and Hall of Hundred Columns (c. 480-460 BCE) (Photo Ebba Koch).

tan Muhammad b. Tughluq, a vast public audience hall with wooden painted pillars built in 1343 in his palace at Jahanpanah-Delhi; it is likely that this structure represented an allusion to Persepolis and that it inspired Shah Jahan.

In any case, as we have pointed out above, in the seventeenth century Persepolis was known as Chihil Sutun in the sense of a proper name and this "numerical title" contained the only formal information about Persepolis which the Mughal conceptualists had at their disposal when they wanted to allude architecturally to the famous site. So chihil sutun, in the sense of the multi-columned halls of Persepolis, the Diwan-i 'Amms of Shah Jahan had to be, but what form would the numerical concept be given?

All three audience halls follow exactly the same scheme, but they are not all the same size. The biggest hall is that of Agra $(61.48 \mathrm{~m}$ long, $20.72 \mathrm{~m}$ wide and $11.55 \mathrm{~m}$ high); those of Lahore $(54.05 \mathrm{~m}$ long, $18.32 \mathrm{~m}$ wide, original height not known) and Delhi (54.66m long, $18.41 \mathrm{~m}$ wide, $12.66 \mathrm{~m}$ high) are smaller and close to each other in their dimensions (Figs. 7, 8). Each of the Diwan-i- 'Amms shows the same flat-roofed hypostyle construction erected on a grid pattern which 

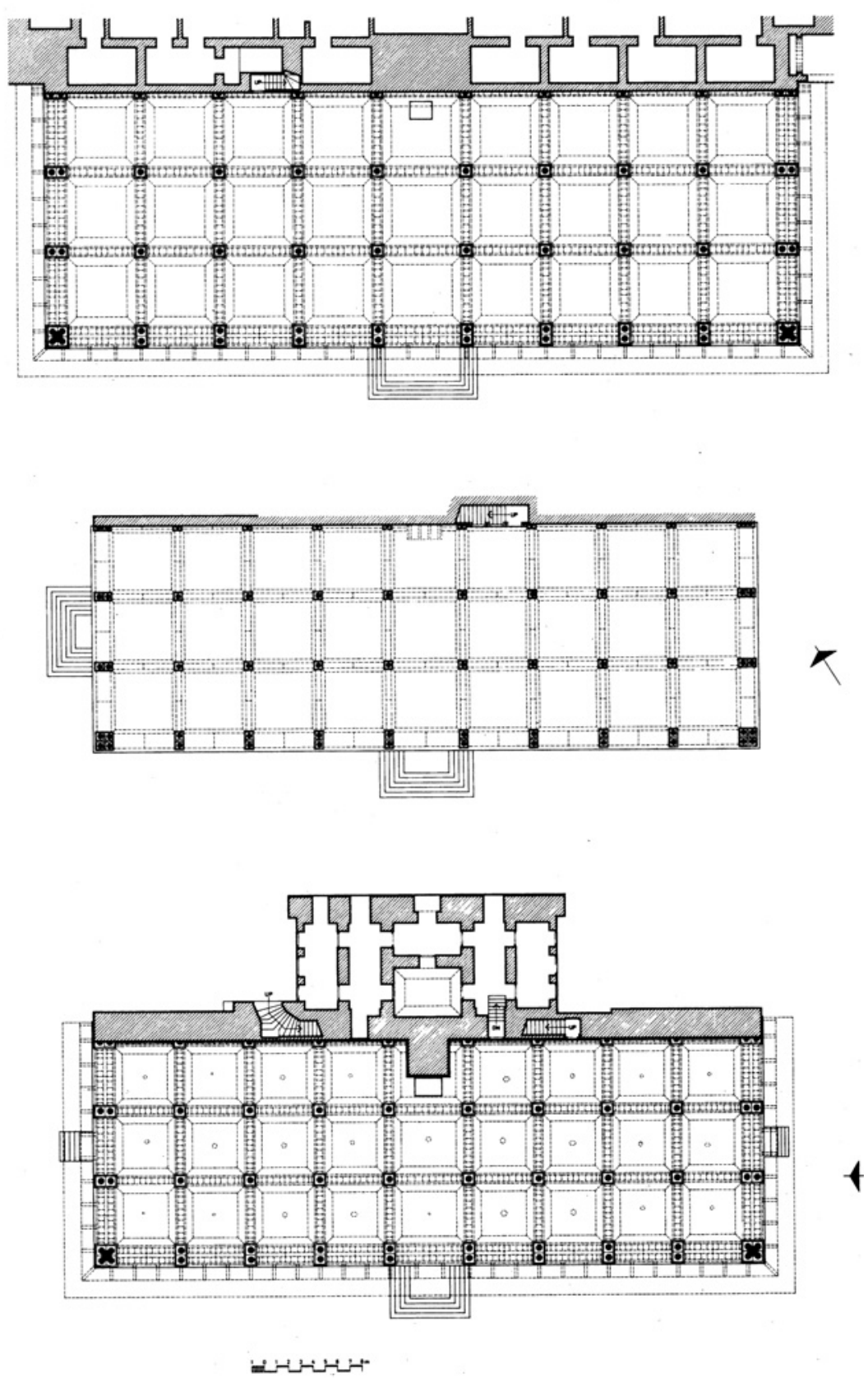

Figure 7. Ground plans of the Diwan-i 'Amms of Agra, Lahore, and Delhi (Drawing: R.A. Barraud and E. Koch). 

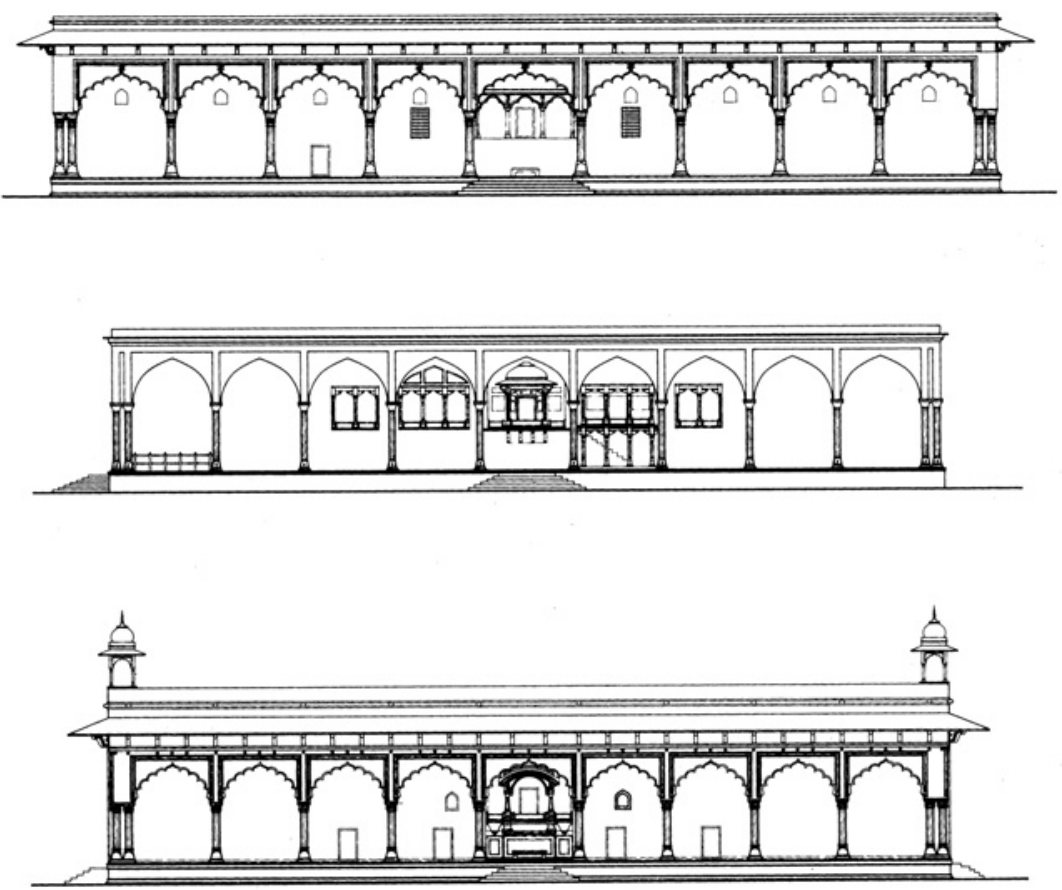

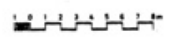

Figure 8. Elevations of the Diwan-i 'Amms of Agra, Lahore, and Delhi (Drawing: R.A. Barraud and E. Koch).

forms twenty-seven bays. The bays are demarcated by coved ceilings (chashma), set off by multi-lobed arches (taq-i marghuldar) and large twelve-sided 'Shahjahani' columns. The columns are paired on the outer sides which produces a quadruple formation in the corners. Each hall thus has forty-eight full columns and twelve half columns. If, however, each columnar unit is read as a single one, we get exactly forty supports, with ten on the longer side of the hall and four on the shorter sides. From this it becomes evident that the Mughals were careful to take the main formal information about Persepolis they had at their disposal, namely its 'numerical title' chihil sutun, as literally as possible. This shows that Shah Jahan's Chihil Sutuns were not merely intended as a Mughal version of the Safavid and Timurid Chihil Sutuns but as a direct reference to what, in the last analysis, could well be the common prototype of all, namely Chihil Sutun-Persepolis. Whereas the Timurid and Safavids referred to it more loosely and perhaps less 
consciously with a hypostyle, columnar hall, the Mughals had the ambition to come up with what they took to be the most authentic reproduction of the original. As often happens, the periphery here is more literal than the center, 'more catholic than the Pope.'

Moreover, in medieval architecture numbers were among the prominent elements that would determine the relationship between copy and original; a point stressed by Krautheimer in his pivotal study on the subject. ${ }^{20} \mathrm{He}$ showed that medieval thinkers felt perfectly justified in relating buildings to one another as long as some of the outstanding elements seemed to be comparable. In addition to numbers, often only the name of a building was considered sufficient to arouse associations connected with the prototype. Since in the case of Chihil Sutun-Persepolis the name was actually a number, it offered itself as the determining factor for the Mughal copy.

\section{Audience Hall and Mosque}

In any case, because of its ruined state, Persepolis could not serve as a model for the arrangement of these forty columns. For models of the layout of the Diwan-i 'Amms we do not have to look at Persia; its sources can be found closer to home, namely, within Mughal architecture itself. Shah Jahan's Diwan-i 'Amms have an overall scheme of a hall constructed over a grid pattern, with paired pillars around the periphery. Their oblong shape generates three aisles along the longer side and nine naves along the shorter side. This plan has its closest parallel in the mosque known as Patthar Masjid at Srinagar (Fig. 9), said to have been built by Jahangir's wife Nur Jahan. The traditional attribution of the mosque to this patroness of architecture is corroborated by the stylistic evidence which points to the 1620s. The prayer hall of the Patthar Masjid is built in a more massive idiom than the Diwan-i 'Amm halls, with cruciform piers instead of columns. Both buildings have a wider nave in the center, indicating the direction in which the hall should be read. In the case of the mosque it leads to the mihrab, the arched niche in the qibla wall towards which prayer is directed, in the case of the audience hall to the emperor's place of appearance, the jharoka.

\footnotetext{
${ }^{20}$ Richard Krautheimer, 'Introduction to an "Iconography" of Medieval Architecture', Journal of the Warburg and Courtauld Institutes 5 (1942) pp. 1-33.
} 


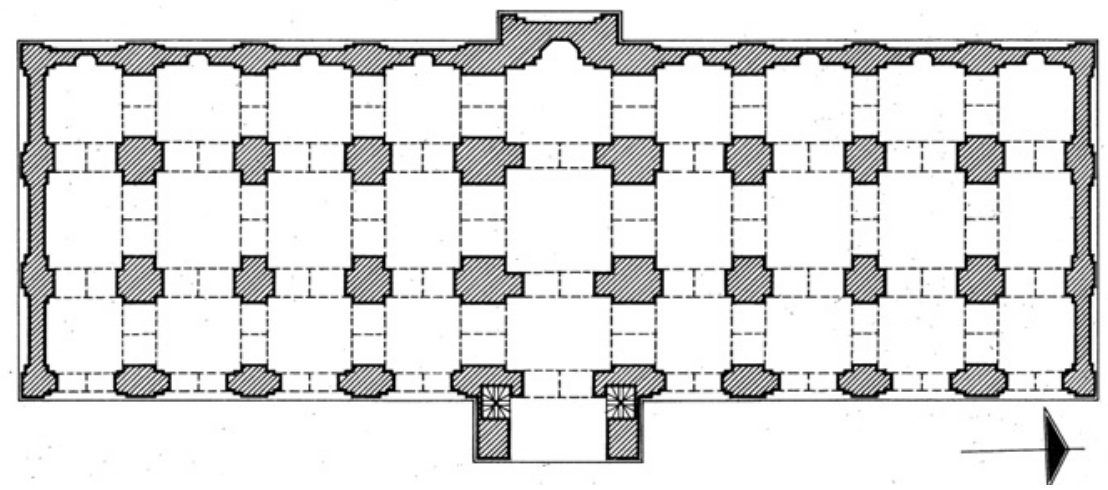

Figure 9. Ground plan of the Patthar Masjid, Srinagar, 1620s (Drawing: R.A. Barraud and E. Koch).

Such parallels are by no means accidental: Shah Jahan's eulogists extol the emperor as the qibla and mihrab of his subjects. Here is Abu Talib Kalim:

May his court always be revered

May it be like the Ka' ba a qibla for the seven climates! ${ }^{21}$

And, more specifically, as if to illustrate our argument, Qazwini describes the emperor holding court in the Diwan-i 'Amm as qibla-i hajat, the place to which people turn for the attainment of their wants. ${ }^{22}$

The connection between audience hall and mosque was in the palace of Agra-which is the only place where the greater architectural context of a Diwan-i 'Amm of Shah Jahan is preserved-reinforced by an additional architectural accent. When we look at the plan of the Agra fort, we notice that the hall (Fig. $4 \mathrm{~b}$ ) sets the main accent of the eastern wing of the courtyard of public audiences (Fig. 4a). The central part of the western wing of the audience courtyard-that is, the section situated exactly opposite the audience hall-was given the shape of a mosque-a fact which has hitherto gone unnoticed (Fig. 4c). The raised central part, which projects slightly from the plane of the courtyard wings represents the facade of the mosque which has five

${ }^{21}$ Abu Talib Kalim, Diwan, Partaw Bayza'I, ed. (Tehran 1336 sh/1957) p. 373.

${ }^{22}$ Muhammad Amin Qazwini, or Amina-i Qazwini, Padshahnama, BL, ms. Or. 173, fol. 138a. 
domed bays flanked on each side by stairs leading up to the roof; in the center is a mihrab. Since Shah Jahan had originally no congregational mosques built in his palaces (the Moti Masjid of the Agra Fort was constructed only towards the end of his reign), it appears that the audience courtyard was also used as a mosque courtyard. The narrow arcaded galleries surrounding the Sahn-i Khass-u- 'Amm corresponded in shape and designation to those of mosque courtyards of the period (cf. Figs. 4 and 10). It is significant that the Jharoka of the audience hall in the east and the mihrab of the prayer hall in the west were set on the same axis (Figs. $4 \mathrm{a}$ and c). With regard to form and content, the whole arrangement conformed to the concept of qarina ("counter image") which was the governing principle of planning in Shahjahani architecture and art. Here it had to express that the Jharoka marked the emperor's own qibla as opposed to that oriented to Mecca. The imperial qibla was the east because it related to the sun rulership of Shah Jahan; the Jharoka-i Khass-u-'Amm where the emperor presented himself before the eyes of his subjects was perceived as the 'rising place of the sun of the sky of the empire and caliphate (matla' -i khurshid-i asman-i dawlat wa khilafat). ${ }^{23}$

The parallels between audience hall and mosque are all the more noteworthy, since Shah Jahan originally had no congregational mosques built in his palaces; the Moti Masjid of the Agra Fort was constructed only in 1647-53 (Figs. 10, 11). It is of special interest in our context that the Moti Masjid represents the grandest expression of a type of Shahjahani mosques which can be traced back formally to the same source as the audience halls, namely, the Patthar Masjid at Srinagar (Fig. 9). Like that of the audience halls, its plan is based on a grid system of bays. But in contrast to the audience halls, the central nave of these mosques which leads to the mihrab is not wider than the aisles flanking it. In the Moti Masjid of the Agra Fort this idea is pushed even further in that the nave leading to the mihrab is minimized by a shift of axis. The main axis is here the one parallel to the qibla wall and not the one perpendicular to it. This is obvious from the treatment of the aisles. It is the central aisle parallel to the qibla wall which is wider and emphasized, in addition, by the insertion of three

${ }^{23}$ I am studying the sun rulership of Shah Jahan and its European connections. See Koch, 'The Hierarchical Principles of Shah-Jahani Painting', p. 160; cf. Necipoğlu, 'Framing the Gaze', p. 317. 


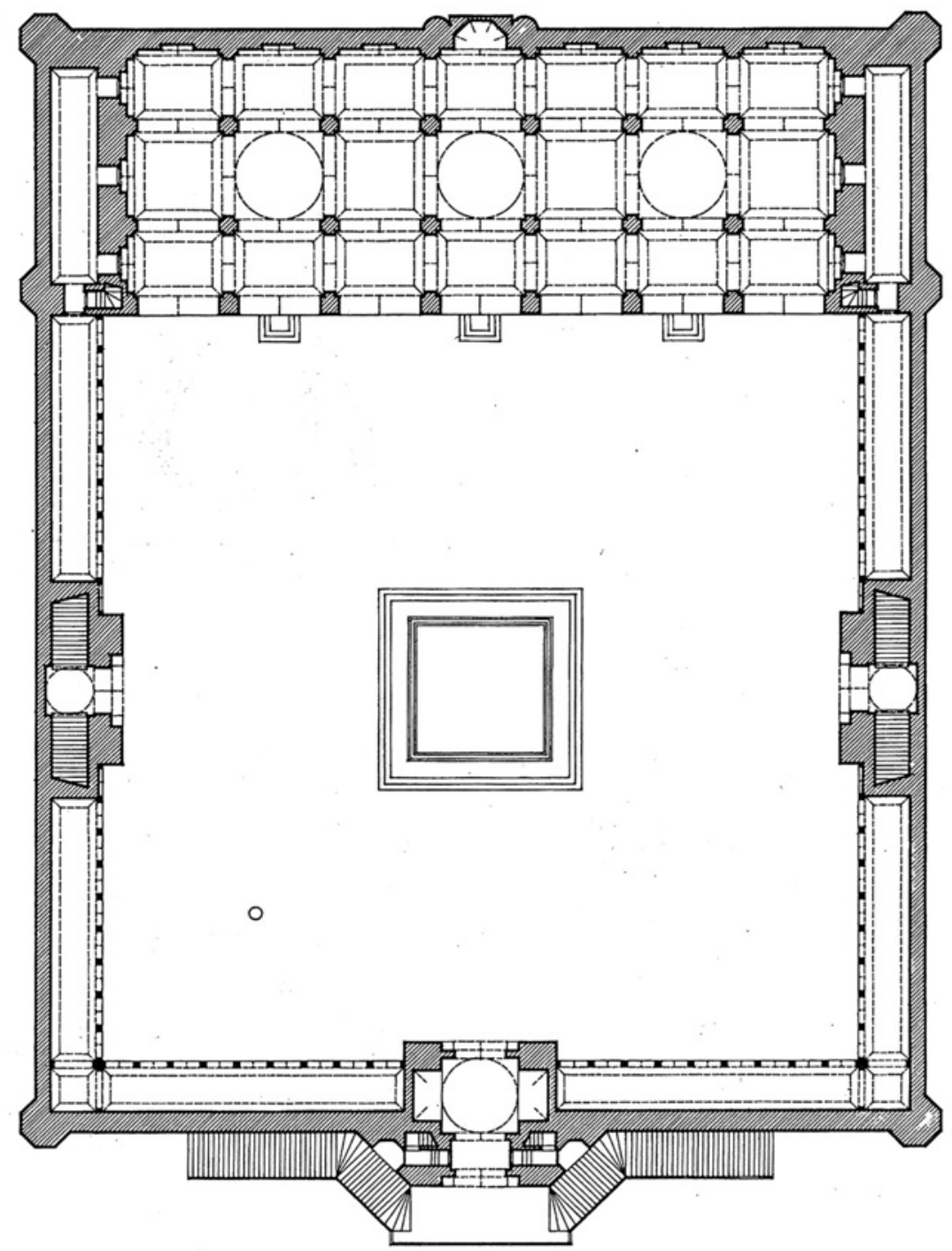

Figure 10. Main-floor plan of the Moti Masjid, Agra Fort, 1647-53 (Drawing: R.A. Barraud and E. Koch). 


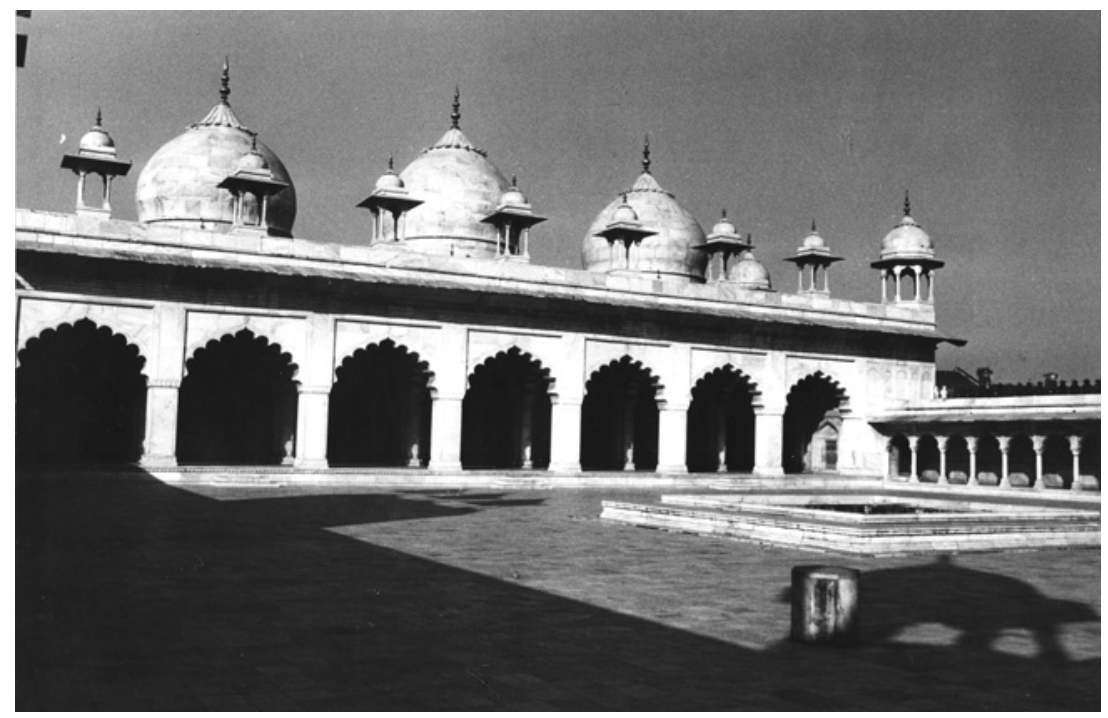

Figure 11. Facade of the prayer hall, Moti Masjid, Agra Fort (Photo Ebba Koch).

domes which alternate with the coved ceilings, used otherwise-as in the audience halls-as covering for the bays. On the outside, this orientation is highlighted by three outer domes set above the inner ones. The Shahjahani mosques with a special royal connotation had to cede their most highly charged symbolic feature, namely, the wider central mihrab nave, to the palatial audience halls.

These connections between mosque and audience hall take us back to the earliest period of Islamic architecture, much debated to the present day. Shah Jahan's audience halls support, in reverse and retrospect, over time and space, the hypothesis of Jean Sauvaget who in 1947 suggested that the mihrab and the axial nave of the earliest Umayyad mosques, such as the great mosque of Damascus (706) were borrowings from the palace: they 'emphasize[d] the area reserved to the prince, and imitated a palace throne room. ${ }^{24}$ In other words, the

${ }^{24}$ Jean Sauvaget, La mosquee omeyyade de Medine: Etude sur les origins architecturales de la mosquee et de la basilique (Paris 1947); English translation 'The Mosque and the Palace', in: Jonathan M. Bloom ed., Early Islamic Art and Architecture (Aldershot Hampshire 2002) pp. 109-147. 
early mosques were enhanced with a feature of worldly authority, which acquired over the centuries a purely religious meaning. ${ }^{25}$

One wonders whether and how the Mughals knew about these early connections between mosque and audience halls; what they certainly knew was that the pillared audience halls of Chihil Sutun-Persepolis evoked in the Islamic traditions associations with mosques. The early Arab geographers of the 10th century who were certainly read at the Mughal court had described it as masjid-i Sulayman. In this context the reason given by Shah Jahan's court historians for the construction of the Diwan-i 'Amms - to protect the emperor's courtiers from sun and rain-acquires a new meaning. The passage seems to have to do less with a genuine concern of Shah Jahan but rather with a literary trope, namely of the reason given by Arab sources for the construction of the first mosque of Islam, taken to be a covered hall of palm trunks supporting a roof of woven palm branches and mud in the prophet Muhammad's house at Medina, to protect his followers from the sun. ${ }^{26}$ And we remember also, that the pillars of the Agra hall were seen by Kalim poetically as cypresses, as trees. One of the fascinating aspects of the Mughals is their historicity and that they preferred to actualize for the construction of their identity as rulers themes from the past which had multiple meanings, which could cover more than one aspect of their self-propagated image. It seems thus quite possible that Shah Jahan (or whoever advised him) undertook his reconstruction of the royal halls of Persepolis with an eye on the prophet Muhammad, sheltering, like him, his followers with an hypostyle-pillared hall patterned on a mosque.

In any case, Shah Jahan's claim to unite, as a universal ruler, spiritual and political authority could not have been given clearer architectural expression. The Mughal emperor, as heir to the Persian kings and a second Solomon, held audience in a pillared hall where he appeared

${ }^{25}$ Cf. Robert Hillenbrand, Islamic architecture: form, function and meaning (Edinburgh 1994) p. 16, for an assessment of the mutual influence between mosque and palace in the early period of Islamic architecture that "each building type received an added charge from the other".

${ }^{26}$ See L. Caetani, Annali dell' Islam vol. 1 (Milan 1905) p. 377; see also Robert Hillenbrand, Islamic Architecture (Edinburgh 1994) p. 40. J. Johns, 'The "House of the Prophet" and the Concept of the Mosque', in: Bayt al-Maqdis, Jerusalem and Early Islam, Oxford Studies in Islamic Art, vol. IX, part 2 (Oxford 1999) pp. 59-112, questioned in thorough investigation the archaeological and historical probability of the tradition of long standing that the origin of the mosque was in the house of the prophet but does not dispute the reason for its construction as a protection from the sun. 
(like a Hindu idol) in a jharoka, positioned in the hall like a mihrab, to symbolize that he was the qibla of his subjects and al-zill Allah, or the Shadow of God on Earth. In his last audience hall at Delhi, Shah Jahan's claim was reinforced by a spectacular realisation of the Jharoka, which formally stands for the mihrab. It was given the shape of a huge Solomonic throne, with its characteristic components, namely supports in the form of artificial trees, with birds and lions on the niche behind it. They were expressed in Florentine and Mughal commesso di pietre dure, or inlay with semi-precious stones, topped by the image of the beast-charming Orpheus, who symbolizes the Solomonic justice of Shah Jahan. ${ }^{27}$

Shah Jahan's audience hall emerges as an ingenious and creative historical reconstruction which transforms a vague numerical concept into the purposeful logic of a building, planned perfectly as a manifesto of the emperor's rule. But then, who after all would have ever believed in the first place that Shah Jahan's audience halls were constructed merely as a shelter against sun and rain?

${ }^{27}$ Ebba Koch, Shah Jahan and Orpheus: The Pietre Dure Decoration and the Programme of the Throne in the Hall of Public Audiences at the Red Fort of Delhi (Graz 1988). 